\title{
Phytoprotection
}

\section{Growth and isoenzyme comparison of five isolates of Venturia inaequalis}

\author{
E. Roig, P. Neumann et J.-P. Simon
}

Volume 71, numéro 2, 1990

URI : https://id.erudit.org/iderudit/705984ar

DOI : https://doi.org/10.7202/705984ar

Aller au sommaire du numéro

Éditeur(s)

Société de protection des plantes du Québec (SPPQ)l

ISSN

0031-9511 (imprimé)

1710-1603 (numérique)

Découvrir la revue

Citer cet article

Roig, E., Neumann, P. \& Simon, J.-P. (1990). Growth and isoenzyme comparison of five isolates of Venturia inaequalis. Phytoprotection, 71(2), 65-71.

https://doi.org/10.7202/705984ar
Résumé de l'article

Nous avons observé l'aspect du mycélium de cinq isolats du Venturia inaequalis. Des différences ont été constatées entre les différents isolats des races et l'isolât de la race 3 se distingue le plus des autres. Quinze systèmes enzymatiques et les protéines non-spécifiques ont été testés par électrophorèse sur gel de polyacrylamide ou d'amidon. Treize des systèmes enzymatiques ainsi que les protéines non-spécifiques révélées ne montraient pas de variation entre les isolats des races. Le patron isoenzymatique des esterases permet de séparer ces isolats car une seule isoenzyme est commune à tous et deux autres ne se retrouvent que chez les isolats des races 1 et 5 . Une isoenzyme de F anhydrase carbonique est spécifique à l'isolât de la race 2 . 


\title{
Growth and isoenzyme comparison of five isolates of Venturia inaequalis
}

\author{
Eva Roig, Peterjürgen Neumann, and Jean-Pierre Simon \\ Département de sciences biologiques, Université de Montréal \\ C.P. 6128, Succursale A, Montréal (Québec), Canada H3C $3 \mathrm{~J} 7$
}

(Received 1989-06-21; accepted 1990-03-20)

\begin{abstract}
Observation of the mycelial aspect of five isolates representing the five races of Venturia inaequalis indicates that it is possible to differentiate these isolates by their growth pattern and the isolate of race 3 appears to be the most easily distinguishable. Fifteen enzyme systems and non-specific proteins have been analyzed by polyacrylamide and starch gel electrophoresis. Thirteen of the isoenzymes systems and non-specific proteins showed no variation among the five isolates. Esterases isoenzyme patterns allow separation of the isolates since only one isoenzyme is common to all isolates and two others are shared by isolates of race 1 and 5 . One carbonic anhydrase isoenzyme was observed to be specific to the isolate of race 2 .

Roig, E., P. Neumann, and J.-P. Simon. 1990. Growth and isoenzyme comparison of five isolates of Venturia inaequalis. PHYTOPROTECTION 71 : $65-71$.

Nous avons observé l'aspect du mycélium de cinq isolats du Venturia inaequalis. Des différences ont été constatées entre les différents isolats des races et l'isolat de la race 3 se distingue le plus des autres. Quinze systèmes enzymatiques et les protéines non-spécifiques ont été testés par électrophorèse sur gel de polyacrylamide ou d'amidon. Treize des systèmes enzymatiques ainsi que les protéines non-spécifiques révélés ne montraient pas de variation entre les isolats des races. Le patron isoenzymatique des estérases permet de séparer ces isolats car une seule isoenzyme est commune à tous et deux autres ne se retrouvent que chez les isolats des races 1 et 5 . Une isoenzyme de l'anhydrase carbonique est spécifique à l'isolat de la race 2 .
\end{abstract}

\section{Introduction}

The apple scab fungus, Venturia inaequalis (Cke) Wint., is a major pathogen of apple (Malus domestica Borkh.), as it attacks almost all varieties. It infects leaves, flowers and fruits and makes the latter unfit for sale. Palmiter (1934) described in vitro variations in morphological and physiological characters of the fungus and Herbst et al. (1937) assumed that the morphotypes of this fungus constituted hereditary races. Five races have been identified by their specific virulence on different varieties of apple (Julien and Spangelo 1957; Shay and Williams 1956; Shay et al. 1962; Williams and Brown 1968). Race 1 is commonly encountered in Northern America and Europe (Shay and Williams 1956). Race 2 was collected in Southern Dakota and attacks the Dolgo variety, some seedlings of Russian origin (R12740-7A) and the Geneva variety. Race 3 collected in Nova Scotia is virulent against the Geneva variety (Shay and Williams 1956). Race 4 has been isolated from

$\overline{0031-9511 / 90} \$ 1.00+.10$ seedlings R12740-7A that were previously resistant to race 2 (Shay et al. 1962). Race 5 appeared simultaneously in France and in England in 1968 and attacks plants possessing the $V_{m}$ gene for resistance (Williams and Brown 1968).

Polyacrylamide and starch gel electrophoresis have been used widely to classify organisms at various taxonomic levels. Chang et al. (1962) applied them to Neurospora sp., Clare (1963) to species of Pythium, and Durbin (1966) to Septoria sp. Differences in the protein bands of two races of Puccinia graminis Pers. were found (Macko et al. 1967) but Shipton and Fleischmann (1969) were unable to differentiate two races of Puccinia coronata Corda on the basis of disc gel electrophoresis of soluble proteins. Howes et al. (1982), using two-dimensional isoelectric focusing (IEF) coupled with polyacrylamide gel electrophoresis, found that each of four races of Puccinia graminis f. sp. tritici Pers. Eriks. $\&$ E. Henn. had a unique combination of polypeptides and some of these could be associated with specific fungal genes for virulence. Kim et al. (1984) have associated a group of polypeptides with races that are 
avirulent or virulent on hosts with specific genes for resistance or susceptibility. Differences in isoenzyme and protein patterns of five isolates of Cryphonectria cubensis (Bruner) Hodges were detected by Alfenas et al. (1984). Two races of the aggressive strain of Ophiostoma ulmi (Buism.) Nannf. were differentiated by Jeng et al. (1988) using isoenzyme and protein patterns.

Although electrophoretic techniques have been used extensively in fungal taxonomy, electrophoresis of isoenzymes has not been too much utilized to identify and characterize strains, formae speciales, isolates or races of fungi differing in pathogenicity. A study was initiated to determine the isoenzyme and protein patterns of five isolates representing the five races of Venturia inaequalis used in resistance testing and dwarf apple tree selection program by polyacrylamide and starch gel electrophoresis. The purpose of this study was to characterize this material more thoroughly and to have a basis for classifying other isolates.

\section{Materials and methods}

Culture procedure. Stock cultures were supplied by Agriculture Canada Research Station, Saint-Jean-sur-Richelieu, Québec. Each race was represented by one isolate. Those isolates were kept under mineral oil in culture tubes maintained at $4{ }^{\circ} \mathrm{C}$. They were inoculated on malt extract agar and kept at room temperature $\left(20 \pm 2{ }^{\circ} \mathrm{C}\right)$. For diametral growth measurements, the inoculum was a standardized disk $(5 \mathrm{~mm})$ cut from the perimeter of a 25-day-old colony with a No. 2 cork borer. Two series of four replicates of cultures of each isolate were observed and diametral growth and morphological characters of the cultures were recorded after 23 and 40 days of growth. For dry weight determination, the fungus was grown in liquid medium $(10 \mathrm{~mL})$ consisting of malt extract $2 \%, \mathrm{pH} 6.0$ (Difco) in square bottles $(120 \mathrm{~mL})$ placed on their side. After 20 days of growth at room temperature, the mycelium of 21 bottles was harvested by filtration, rinsed with distilled water, freeze-dried and weighed. A oneway ANOVA analysis was conducted for both types of cultures using the Number
Cruncher Statistical System (NCSS) (Hintze 1986).

Protein extraction. The freeze-dried mycelium was ground in a chilled $\left(4^{\circ} \mathrm{C}\right)$ mortar. The extracting solution used for polyacrylamide gel electrophoresis was 0.1 $\mathrm{M}$ tris-HC1, pH 6.7 and containing $40 \%$ sucrose. For starch gel electrophoresis, the extracting solution was $0.1 \mathrm{M} \mathrm{KH}_{2} \mathrm{PO}_{4}$ buffer, $\mathrm{pH} 8.0$ and containing $20 \%$ sucrose and $20 \mathrm{mg} / \mathrm{mL}$ polyvinylpyrrolidone $\mathrm{P}-40$ (Sigma). The slurry was centrifuged at $4^{\circ} \mathrm{C}$ for $10 \mathrm{~min}$ at $600 \mathrm{~g}$ and the supernatant was used for electrophoresis.

Electrophoresis. Polyacrylamide gel electrophoresis (PAGE) using the discontinuous buffer system described by Simon (1986) was performed vertically in a simplified apparatus according to Chapel et al. (1974) and Raymond (1964). Depending on the enzyme system to be analyzed, two different buffers were used for the starch gel electrophoresis. A quantity of $42.4 \mathrm{~g}$ of starch (Electrostarch, Electrostarch Company) were mixed with $400 \mathrm{~mL}$ of a $0.18 \mathrm{M}$ tris-EDTA buffer, $\mathrm{pH} 8.4$, diluted five times for the detection of alkaline phosphatase and carbonic anhydrase. For the analysis of the other systems, we used a $0.036 \mathrm{M}$ tris-citrate buffer, $\mathrm{pH} 7.5$, diluted five times. The electrode compartments were filled with the same undiluted buffers. For the analysis of the dehydrogenases, NAD or NADP was added to the gel $(35 \mu \mathrm{mol})$ before polymerisation and to the electrode compartments $(70 \mu \mathrm{mol})$. Electrophoresis was carried out horizontally at a constant current of either $35 \mathrm{~mA}(160 \mathrm{~V})$ for the trisEDTA buffer and $50 \mathrm{~mA}(100 \mathrm{~V})$ for the tris-citrate buffer. The electrophoretic separation was achieved within 4 to $6 \mathrm{~h}$ at $4^{\circ} \mathrm{C}$. The gel slab was covered with an Ice-pak ${ }^{\circledR}$ to prevent warming.

Isoenzymes were visualized by the methods described by Ayala et al. (1972), Harris and Hopkinson (1976), Scandalios (1969), and Shaw and Prasad (1970), using acrylamide or starch gel electrophoresis. General proteins were detected following the method of Chrambach et al. (1967). Each experiment was replicated at least twice on independent extracts. The relative mobilities $\left(R_{f}\right)$ with reference to the Kohl- 
rausch band (acrylamide gels) or the buffer front (starch gels) were recorded.

\section{Results and discussion}

Morphological characters. Each of the five isolates presents a peculiar colony according to its margin and aspect of mycelial mat (Table 1) that was maintained over a two-year period of observation. The isolate of race 3 is the most different. It produces woolen-like mycelial threads that radiate and can be noticed as soon as the fungus starts growing. In contrast to isolate of race 1 , the isolate of race 2 grows well into the agar and presents a well-defined colony margin and a brown colouration in the surrounding area of the colony. This colouration appears to be the consequence of the production of a melanoprotein-like pigment (Hignett et al. 1977). The isolate of race 4 resembles that of race 2 . The isolate of race 5 looks like the isolate of race 1 but shows growth rings on the back of the Petri dish. In addition, greyish white sectors replace the usual greyish green colour and almost no conidia are produced. The isolate of race 5 may have undergone a mutation process since it has been proved by a study on conidial production of the five races that the original stock of race 5 produces conidia (Ross 1974). It is also possible that the race 5 has a particular temperature optimum for sporulation since cultures isolated from different hosts produce spores at higher temperatures while others cannot produce them at temperatures above $20^{\circ} \mathrm{C}$ (Barakat et al. 1982).

Differentiation of each isolate is also possible when grown in liquid media (Table 1). Some isolates produce a mycelial mat on the bottom of the flasks (isolates of races 1, 3 and 4) while others develop small isolated colonies (isolates of races 2 and 5). The mycelium of the isolate of race 3 is not fixed on the bottom of the flask and sets apart in one block. While the colour of the culture medium is pale yellow, it turns dark green when colonized by isolates of races 2 and 3 due to the presence of fungal pigments. After three weeks of growth in the liquid medium, these characteristics fade out and it becomes more difficult to differentiate those isolates.

Table 1. Morphological characters of the five isolates of Venturia inaequalis after 23 days of growth on malt agar (a) or 20 days of growth in malt extract broth (b)

\begin{tabular}{|c|c|c|}
\hline Isolate & Culture medium & Morphological characters ${ }^{\S}$ \\
\hline \multirow[t]{2}{*}{1} & $\mathrm{a}$ & $\begin{array}{l}\text { Translucent mycelium growth on perimeter, } \\
\text { downy, greyish green. }\end{array}$ \\
\hline & $\mathrm{b}$ & $\begin{array}{l}\text { Coalescent colonies, greyish green, attached } \\
\text { to the bottom of the flask. }\end{array}$ \\
\hline \multirow[t]{2}{*}{2} & $\mathrm{a}$ & $\begin{array}{l}\text { Thick mycelium, velvety, greyish dark } \\
\text { green. }\end{array}$ \\
\hline & $\mathrm{b}$ & Isolated colonies, dark green. \\
\hline \multirow[t]{2}{*}{3} & a & Woolly, dark grey to olive green. \\
\hline & $\mathrm{b}$ & $\begin{array}{l}\text { Mycelial mat, green, not attached on the } \\
\text { bottom of the flask. }\end{array}$ \\
\hline \multirow[t]{2}{*}{4} & a & $\begin{array}{l}\text { Thick mycelium, less defined margin than } \\
\text { isolate } 2 \text {. Velvety-downy, browny green. }\end{array}$ \\
\hline & $\mathrm{b}$ & Mycelial mat, browny green. \\
\hline \multirow[t]{2}{*}{5} & a & $\begin{array}{l}\text { Looks like isolate } 1 \text {, growth rings greyish } \\
\text { green and greyish white sectors. }\end{array}$ \\
\hline & $\mathrm{b}$ & $\begin{array}{l}\text { More or less isolated colonies, greyish } \\
\text { green. }\end{array}$ \\
\hline
\end{tabular}


To estimate their growth rate, we measured the diameter of the colonies over a period of 65 days (Fig. 1). The isolate of race 3 showed always the largest diameter and the isolate of race 1 had the smallest one. With one exception, the growth of isolates of races 1 and 3 was always significantly different $(P \leq 0.05)$ from all the other isolates using the Fisher and Duncan tests when measured at 15,25 or 38 days of growth. After 65 days of growth, the mean diametral growth of isolates 1, 3 and 4 were significantly different from all the other isolates $(P \leq 0.05)$. The isolate of race 3 produced the highest dry weight while the smallest dry weight was observed for the isolate of race 5 (Fig. 2). Weight differences between all pairs of isolates were significant $(P \leq 0.05)$ except between isolates of races 1 and 2 . Of all isolates, race 3 was easily distinguishable by the type of mycelial surface as well as by its higher growth rate and dry weight production. However, the other isolates show particular mycelium characteristics that permit them to be readily differentiated after a three-week period on agar.

Electrophoretic analysis. Fifteen enzyme systems were resolved in our study, two of them by PAGE and thirteen in starch gels (Table 2; Fig. 3). In addition, general soluble proteins were also detected by PAGE. Repeated attempts to analyze acid phosphatases (ACP), glutamate-oxalacetate transaminase (GOT) and peroxidases (PX) using both types of gels gave poorly resolved patterns which could not be analyzed with confidence. No variation in the mobility of isozymes among the five $V$. inaequalis isolates were observed for thirteen systems (Fig. 3). Isozyme patterns of glucose-6phosphate dehydrogenase (G-6-PDH), alcohol dehydrogenase (ADH), phosphoglucose isomerase (PGM), malic enzyme (ME), leucine aminopeptidase (LAP), malate dehydrogenase $(\mathrm{MDH})$, lactic dehydrogenase (LDH), isocitrate dehydrogenase (IDH) and 6-phosphoglucose dehydrogenase (6-PGD) showed one isozyme of similar electrophoretic mobility in the electropherograms of the five $V$. inaequalis isolates.

Invariant patterns were also observed for the two component isozyme patterns of glutamic dehydrogenase (GDH), alkaline phos-

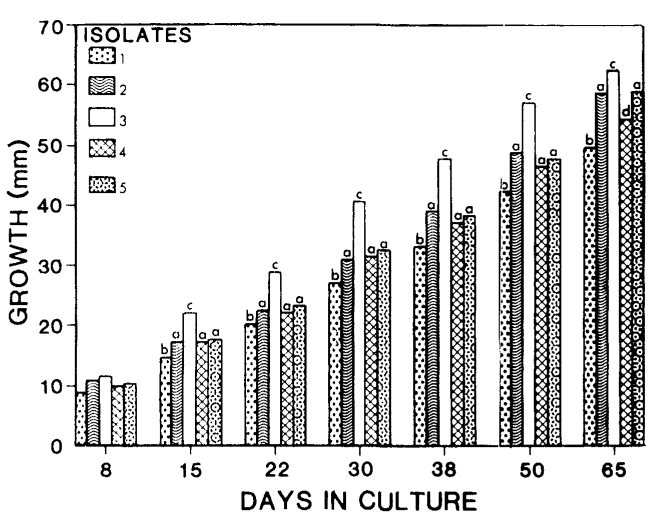

Figure 1. Mean diametral growth of the five isolates of $V$. inaequalis grown on malt extract agar (four replicates). Identical letters indicate means of values not significantly different $(P>0.05)$ according to Duncan's multiple range test.

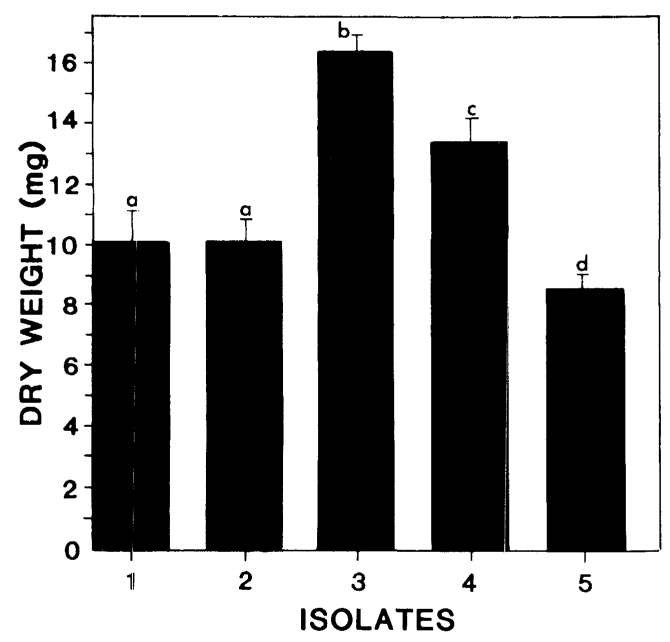

Figure 2. Mean dry weight of the five isolates of $V$. inaequalis grown for 20 days in malt extract broth ( 21 replicates). Identical letters indicate means of values not significantly different $(P>0.05)$ according to Duncan's multiple range test.

phatase (AKP) and phosphoglucose isomerase (PGI), and for superoxide dismutase (SOD) with a more complex pattern of seven isozymes. General soluble protein (GP) patterns with four well-defined bands were identical for all isolates. Only two enzyme systems, esterase (EST) and carbonic anhydrase (CA) showed variations in the electropherograms that were specific to some of the isolates. The electropherograms of EST analyzed by PAGE revealed two 
Table 2. Enzyme systems assayed after polyacrylamide (A) and starch (S) gel electrophoresis and staining procedures

\begin{tabular}{llc}
\hline Enzyme & \multicolumn{1}{c}{ Staining procedure } & Gel \\
\hline Esterase (EST) & Scandalios (1969) & A \\
Superoxyde dismutase (SOD) & Ayala et al. (1972) & A \\
Acid phosphatase (ACP) & Scandalios (1969) & A \\
Peroxidase (PX) & Scandalios (1969) & A \\
Glutamate-oxalacetate transaminase (GOT) & Shaw and Prasad (1970) & A \\
General proteins (GP) & Chrambach et al. (1967) & A \\
Carbonic anhydrase (CA) & Harris and Hopkinson (1976) & S \\
Glucose-6-phosphate dehydrogenase (G-6-PDH) & Harris and Hopkinson (1976) & S \\
Isocitrate dehydrogenase (IDH) & Harris and Hopkinson (1976) & S \\
6-phosphogluconate dehydrogenase (6-PGD) & Harris and Hopkinson (1976) & S \\
Glutamate dehydrogenase (GDH) & Harris and Hopkinson (1976) & S \\
Alcohol dehydrogenase (ADH) & Harris and Hopkinson (1976) & S \\
Lactate dehydrogenase (LDH) & Harris and Hopkinson (1976) & S \\
Malate dehydrogenase (MDH) & Harris and Hopkinson (1976) & S \\
Malic enzyme (ME) & Harris and Hopkinson (1976) & S \\
Phosphoglucose isomerase (PGI) & Harris and Hopkinson (1976) & S \\
Phosphoglucomutase (PGM) & Harris and Hopkinson (1976) & S \\
Glutamate-oxalacetate transaminase (GOT) & Shaw and Prasad (1970) & S \\
Leucine aminopeptidase (LAP) & Shaw and Prasad (1970) & S \\
Alkaline phosphatase (AKP) & Scandalios (1969) & S \\
\hline
\end{tabular}

(isolate of race 1) to four isozymes (isolate of race 2 ). Two low $R_{f}$ isozymes for isolates of race 2 (band $b$ ) and 5 (band a) distinguish these isolates from the others (Fig. 3). A well-stained isoenzyme (band e) was only shared by isolates of races 1 and 5 (Fig. 3). Two fast migrating isozymes were present in the isolate of race 2 , but their activities were too faint to use them as reliable markers (Fig. 3, band f). Isolates of races 3 and 4 were not easily distinguished although in $60 \%$ of the replicated experiments we observed band $\mathrm{c}$ in the isolate of race 4 that was never observed in the other four isolates
(Fig. 3). Staining for the enzyme carbonic anhydrase (CA) revealed one major difference between the isolate of race 2 and isolates of the other races. One band was typical of the isolate of race 2 .

Burdon et al. (1981) also detected differences in the isoenzyme patterns of EST among formae speciales of $P$. graminis pathogenic to different host species. In addition they noticed differences in the isoenzyme patterns of LAP, PGM and dihydrolipoamide reductase. Alfenas et al. (1984) working with $C$. cubensis, detected

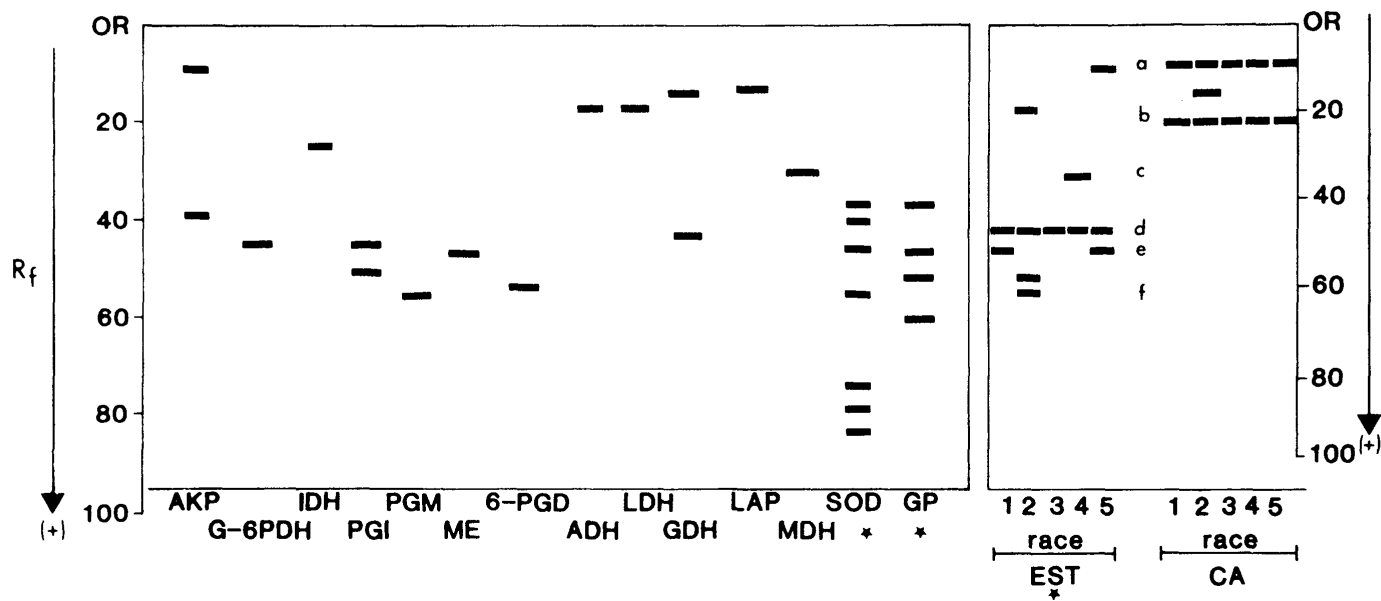

Figure 3. Isoenzyme and general protein banding patterns of $V$. inaequalis as assayed after starch and polyacrylamide* gel electrophoresis. Abbreviations of enzyme systems are given in Table 2. 
differences in the isoenzyme patterns of EST, PX, PGM and hexokinase (HK) among five isolates that differ in virulence. Aggressive and non-aggressive isolates of $O$. ulmi were differentiated using isoenzymes of ADH, EST and PX (Bernier et al. 1983). Very recently, Jeng et al. (1988) reported that isoenzymes of peroxidase, tetrazolium oxidase, and certain protein bands could be used as biochemical markers to distinguish two races of $O$. ulmi. However, formae speciales of Fusarium oxysporum Schlecht. could not be distinguished by their esterase and protein patterns (Meyer and Renard 1969).

Also the non specific proteins of all isolates of $C$. cubensis tested by Alfenas et al. (1984) displayed nearly the same patterns and neither Shipton and Fleischmann (1969) nor Gill and Powell (1968) could separate races of respectively $P$. coronata f.sp. avenae Eriks. and eight races of Phytophthora fragariae Hickman on this basis. However, Macko et al. (1967) and Jeng and Hubbes (1983) were able to differentiate respectively races of $P$. graminis f. sp. tritici and aggressive and non-aggressive isolates of $O$. ulmi. Characterizing races or isolates of fungi by means of protein profiles seems to depend on the organism tested. Our results indicate that only EST isoenzymes could serve as reliable systematic markers for the five isolates of the races of $V$. inaequalis identified by their virulence on differential hosts. It would be desirable to examine the isoenzyme patterns of additional isolates to test this possibility.

We wish to thank Gilles Seutin for his technical advice on electrophoretic techniques and Aileen Farrugia for her valuable help in the preparation of the manuscript. This research was supported by CAFIR, Université de Montréal (P.N.) and NSERC (J.-P. S.).

Alfenas A.C., R. Jeng, and M. Hubbes. 1984. Isoenzyme and protein patterns of isolates of Cryphonectria cubensis differing in virulence. Can. J. Bot. 62: 1756-1762.

Ayala, F.J., J.R. Powell, M.L. Tracey, C.A. Mourao, and S. Perez-Salas. 1972. Enzyme variability in the Drosophila willistoni group: IV. Genic variation in natural populations of Drosophila willistoni. Genetics 70: 113-139.

Barakat, F.M., A.A. El-Shehedi, and R.M. Mahdy. 1982. Induction of better sporulation ability by Venturia inaequalis (Cke) Wint. in culture media. Agric. Res. Rev. Min. Agric. A.R.E. 60: 261-272.
Bernier, L., R.S. Jeng, and M. Hubbes. 1983. Differentiation of aggressive and non-aggressive isolates of Ceratocystis ulmi by gel electrophoresis of intramycelial enzymes. Mycotaxon 17: 456-472.

Burdon J.J., D.R. Marshall, and N.H. Luig. 1981. Isozyme analysis indicates that a virulent cereal rust pathogen is a somatic hybrid. Nature (Lond.) 293: 565-566.

Chang, L.O., A.M. SRB, and F.C. Steward. 1962. Electrophoretic separation of the soluble proteins of Neurospora. Nature (Lond.) 193: 756-759.

Chapel, T., L. Iglesias, A. Barreto, F. Baisre, and J.P. Simon. 1974. Simplified apparatus for vertical slab electrophoresis in polyacrylamide gels. Lab. Pract. 23: 311-312.

Chrambach, A., R.A. Reisfeld, M. Wyckoff, and J. Zaccari. 1967. A procedure for rapid and sensitive staining of protein fractionated by polyacrylamide gel electrophoresis. Anal. Biochem. 20: 150-154.

Clare, B.G. 1963. Starch-gel electrophoresis of proteins as an aid in identifying fungi. Nature (Lond.) 200: 803-804.

Durbin, R.D. 1966. Comparative gel electrophoresis of the protein patterns of Septoria species. Nature (Lond.) 210: 1186-1187.

Gill, H.S., and D. Powell. 1968. Polyacrylamide gel electrophoresis of physiologic races A-1 to A-8 of Phytophthora fragariae. Phytopathology 58: 722-723.

Harris, H., and D.A. Hopkinson. 1976. Handbook of enzyme electrophoresis in human genetics. North-Holland Publishing Co., Amsterdam. 305 pp.

Herbst, W., C.F. Rudloff, and M. Schmidt. 1937. Vergleichend-morphologische Studien an verschiedenen Venturiaarten. Gartenbauwissenschaft 11: 183-207.

Hignett, R.C., J.H. Carder, and A.R.W. Smith. 1977. Origin and characteristics of Venturia inaequalis melanoproteins active in the apple scab disease. J. Gen. Microbiol. 102: 207-210.

Hintze, J.L. 1986. Number Cruncher Statistical System (NCSS). Published by J.L. Hintze, Kaysville, Utah. 269 pp.

Howes, N.K., W.K. Kim, and R. Rohringer. 1982. Detergent-soluble polypeptides extracted from uredospores of four physiologic races of Puccinia graminis f. sp. tritici. Physiol. Plant Pathol. 21: 361-366.

Jeng, R.S., and M. Hubbes. 1983. Identification of aggressive and non-aggressive strains of $\mathrm{Cer}$ atocystis ulmi by acrylamide gradient gel electrophoresis of intramycelial proteins. Mycotaxon 17: 445-455.

Jeng, R.S., L. Bernier, and C.M. Brasier. 1988. A comparative study of cultural and electrophoretic characteristics of the Eurasian and North American races of Ophiostoma ulmi. Can. J. Bot. 66: 1325-1333.

Julien, J.B., and L.P.S. Spangelo. 1957. Physiological races of Venturia inaequalis. Can. J. Plant Sci. 37: 102-107. 
Kim, W.K., J.W. Martens, and N.K. Howes. 1984. Electrophoretic analysis of detergent-soluble polypeptides of nine races of $P$. graminis f. sp. avenae and their relation to $P$. graminis f. sp. tritici. Can. J. Plant Pathol. 6: 111-118.

Macko, V., A. Novacki, and M.A. Stahmann. 1967. Protein and enzyme patterns from urediospores of Puccinia graminis var. tritici. Phytopathol. Z. 58: 122-127.

Meyer, J.A., and J.C. Renard. 1969. Protein and esterase patterns of two formae speciales of Fusarium oxysporum. Phytopathology 59: 1409-1411.

Nobles, M.K. 1965. Identification of cultures of wood inhabiting Hymenomycetes. Can. J. Bot. 43: 1097-1139.

Palmiter, D.H. 1934. Variability in monoconidial cultures of Venturia inaequalis. Phytopathology 24: 22-47.

Raymond, S. 1964. Acrylamide gel electrophoresis. Ann. N.Y. Acad. Sci. 121: 350-365.

Ross, R.G. 1974. Conidium production of Venturia inaequalis in synthetic culture media. Can. J. Plant Sci. 54: 93-100.
Scandalios, J.G. 1969. Genetic control of multiple molecular forms of enzymes in plants: a review. Biochem. Genet. 3: 37-79.

Shaw, C.R., and R. Prasad. 1970. Starch gel electrophoresis of enzymes-A compilation of recipes. Biochem. Genet. 4: 288-296.

Shay, J.R., and W.B. Williams. 1956. Identification of three physiologic races of Venturia inaequalis. Phytopathology 46: 190-193.

Shay, J.R., E.B. Williams, and J. Janick. 1962. Disease resistance in apple and pear. Proc. Am. Soc. Hort. Sci. 80: 97-104.

Shipton, W.A., and G. Fleischmann. 1969. Taxonomic significance of protein patterns of rust species and formae speciales obtained by disc electrophoresis. Can. J. Bot. 47: 1351-1358.

Simon, J.-P. 1986. Molecular forms and kinetic properties of the mitochondrial fraction of NADmalate dehydrogenase in four clones of Lathyrus japonicus (Leguminosae) from sites of contrasting climates. Can. J. Bot. 64: 2675-2681.

Williams, E.B., and A.G. Brown. 1968. A new physiologic race of Venturia inaequalis incitant of apple scab. Plant Dis. Rep. 52: 799-801. 